Дем'янюк О. С., Тертична О. В., Симочко Л. Ю., Свалявчук Л. І.

\title{
УДК 58.073
}

ОСОБЛИВОСТІ ФОРМУВАННЯ МІКРОБІОЦЕНОЗУ ІРУНТУ В ЗОНІ ПРОМИСЛОВОГО БРОЙЛЕРНОГО ВИРОБНИЦТВА

О. С. ДЕМ'ЯНЮК, кандидат сільськогосподарських наук, старший науковий співробітник,

E-mail:demolena@ukr.net

О. В. ТЕРТИЧНА, кандидат біологічних наук, старший науковий співробітник лабораторії реабілітації грунтів відділу екотоксикології Інститут агроекології та природокористування НААН

$$
\text { E-mail: olyater@ukr.net }
$$

Л. Ю. СИМОЧКО, кандидат біологічних наук, доцент, доцент кафедри ентомології та збереження біорізноманіття

\section{ДВНЗ Уэсгородський Національний університет}

E-mail: lyudmilassem@gmail.com

Л. І. СВАЛЯВЧУК, аспірант

\section{Інститут агроекології та природокористування НААН}

E-mail: svaliavchuklarisa@ukr.net

Анотація. Питання екологічного оцінювання мікробіологічного стану трунту в зонах ведення промислового птахівництва є актуальними та важливими для прогнозування подальших змін у біосфері під впливом техногенезу. Метою дослідження було виявити особливості формування мікробіоченозу трунту в зоні бройлерного виробництва за мікробіологічними показниками та фітотоксичним ефектом. Мікробіологічні дослідження трунту проводили загальноприйнятими методами трунтової мікробіологї, розраховували токсичність трунту та фітотоксичний ефект.

Результати мікробіологічних аналізів показали, що спостерігається зміна кількісної структури мікробного ценозу трунту, в залежності від місия локалізації забруднення відходами та побічною продукиією виробництва. Максимальна загальна чисельність трунтових мікроорганізмів відмічено в контрольному, незабрудненому варіанті. Мінімальна кількість органотрофів $\epsilon$

*Науковий керівник - кандидат біологічних наук, старший науковий співробітник О. В. Тертична 
Дем'янюк О. С., Тертична О. В., Симочко Л. Ю., Свалявчук Л. І.

свідченням значного пригнічення мікроорганізмів під впливом токсичних речовин фільтрату відходів. В той же час змінюється склад спорової бактеріальної мікробіоти, найбільше ї̈ у грунті забрудненому метаболітами відходів забійного цүеху та забрудненому фільтратами із пташнику. Збільшення мікроміцетів пояснюється потраплянням у грунт рештків підстилки з тирси, щзо призводить до активізації целюлозоруйнівної мікрофлори. Також у забруднених варіантах порівняно з контрольним зростає чисельність оліготрофів, здатних розвиватися на збіднених грунтах. Кількість педотрофів зменшується, щзо є свідченням зменшення поживних речовин у грунті. Очінено токсичність грунту в зоні промислового бройлерного виробництва з використанням рослинних біотестів Raphanus sativus var. radicula Pers ma Sinapis alba L. Показана більи висока чутливість біотест - об'єкту редису. Гірчиця біла є більи стійкою до дії фітотоксичних метаболітів. Найбільи токсичним виявився грунт, відібраний в 40 м від пташника, забруднений фільтратом відходів.

Отже, мікробіологічний аналіз трунту, забрудненого відходами бройлерного виробництва свідчить про значну трансформаџію мікробних угруповань під впливом токсикантів. Перспективним напрямом подальших досліджень є проведення мікробіологічного моніторингу грунтів в зонах ведення інтенсивного бройлерного виробництва.

Ключові слова: птахівницттво, бройлерне виробницттво, грунт, забруднення, мікроорганізми, фітотоксичність.

Актуальність. Інтенсивне ведення птахівництва за останні роки призвело до виникнення потужних птахопідприємств, які чинять значний антропогенний прес на навколишнє природнє середовище. Вплив на довкілля від отримання птахопродукції різноманітний у залежності від об’єкту впливу: потрапляння в грунт значної кількості метаболітів відходів виробництва, ксенобіотиків; забруднення повітря аерополютантами; утворення значних обсягів стічних вод; трансформація фітоценозу, зменшення біорізноманіття ентомофауни [1]. Грунт $є$ своєрідним депо накопичення полютантів та ксенобіотиків, які можуть мігрувати i інші об’єкти біосфери та трофічними ланцюгами в живі організми [13] . Питання екологічної оцінки мікробіологічного стану грунту в зонах ведення промислового птахівництва є актуальними та важливими для прогнозування подальших змін у біосфері під впливом техногенезу.

Аналіз останніх досліджень та публікацій. Відомо, що грунт знаходиться у центрі всіх біосферних процесів обміну речовини і енергії, відіграє ключову 
Дем'янюк О. С., Тертична О. В., Симочко Л. Ю., Свалявчук Л. І.

роль сполучної ланки між біологічним і геологічним кругообігом, є екологічною нішею для багатьох видів живих організмів $[10,12]$. На думку багатьох провідних вітчизняних вчених В.П. Патики [9], Г. О. Іутинської [3], В.В.Медвєдєва [8], О. В. Шерстобоєвої [11] та ін. мікробіологічні показники грунту, як найбільш інформативні i чутливі, $\epsilon$ необхідною складовою під час проведення комплексного екологічного оцінювання грунтів. На сьогодні недостатньо дослідженими залишаються питання впливу ведення інтенсивного промислового птахівництва на екологічний стан грунту в зонах розташування підприємств із виробництва птахопродукції. Технологія утримання птиці призводить до утворення значних обсягів відходів бройлерного виробництва (використана підстилка, послід, відходи забійного цеху та ін.), що неминуче призводить до забруднення грунту токсикантами.

Мета дослідження - провести екологічну оцінку стану грунту в зоні бройлерного виробництва за мікробіологічними показниками та фітотоксичним ефектом.

Матеріали і методи досліджень. Для дослідження відбирали зразки грунту птахопідприємства 3 виробництва бройлерної продукції, розташованого в Київській області. Тип грунту: дерново-середньо-підзолистий.

Зразки грунту відбиралися в санітарно-захисній зоні (С33) за такими варіантами:

Варіант 1. 10 м від місця тимчасового зберігання відходів забійного цеху.

Варіант 2. 10 м від місця тимчасового зберігання використаної підстилки i посліду.

Варіант 3. 40 м від пташника, забруднення грунту фільтратом відходів.

Варіант 4. 100 м від місця тимчасового зберігання відходів.

Варіант 5. Контроль, за межою С33.

Мікробіологічні дослідження грунту проводили загальноприйнятими методами грунтової мікробіології [7]. Токсичність грунту визначали згідно 3 [2]. Фітотоксичний ефект розраховували відповідно до [4-6] . 
Дем'янюк О. С., Тертична О. В., Симочко Л. Ю., Свалявчук Л. І.

Результати дослідження та їх обговорення. Проведено екологічне оцінювання стану грунту за мікробіологічними показниками в зоні промислового підприємства 3 виробництва бройлерної птахопродукції за мікробіологічними показниками (Табл. 1).

1. Чисельність різних еколого-трофічних груп мікроорганізмів у грунті СЗ3 бройлерного виробництва (КУО в 1 г грунту)

\begin{tabular}{|l|c|c|c|c|c|c|c|}
\hline & Варіант & $\begin{array}{c}\text { Органо- } \\
\text { трофи } \\
10^{6}\end{array}$ & $\begin{array}{c}\text { Мікроор- } \\
\text { ганізми, } \\
\text { бактерії, } \\
10^{5} \\
\text { щасвою- } \\
\text { ють } \\
\text { мінеральні } \\
\text { форми } \\
\text { азоту, } 10^{6}\end{array}$ & $\begin{array}{c}\text { Актиномі- } \\
\text { цети, } 10^{3}\end{array}$ & $\begin{array}{c}\text { Оліготро- } \\
\text { фи, 10 }\end{array}$ & $\begin{array}{c}\text { Педотро- } \\
\text { фи, } 10^{4}\end{array}$ & $\begin{array}{c}\text { Мікромі- } \\
\text { цети, } 10^{3}\end{array}$ \\
\hline Варіант1 & $1,32 \pm 0,2$ & $8,6 \pm 1,63$ & $0,59 \pm 0,04$ & $2,8 \pm 0,03$ & $3,0 \pm 0,2$ & $1,6 \pm 0,35$ & $11,52 \pm 1,9$ \\
\hline Варіант 2 & $2,6 \pm 0,03$ & $6,9 \pm 0,6$ & $1,4 \pm 0,21$ & $4,9 \pm 0,05$ & $2,3 \pm 0,5$ & $4,2 \pm 0,04$ & $23,1 \pm 1,7$ \\
\hline Варіант 3 & $0,81 \pm 0,02$ & $7,4 \pm 0,9$ & $0,79 \pm 0,05$ & $1,8 \pm 0,03$ & $1,5 \pm 0,3$ & $0,12 \pm 0,02$ & $5,8 \pm 1,0$ \\
\hline Варіант 4 & $4,15 \pm 0,6$ & $3,8 \pm 0,5$ & $0,9 \pm 0,02$ & $4,8 \pm 0,6$ & $4,0 \pm 0,4$ & $4,6 \pm 0,75$ & $8,8 \pm 1,4$ \\
\hline $\begin{array}{l}\text { Варіант 5 } \\
\text { контроль) }\end{array}$ & $4,2 \pm 0,6$ & $2,1 \pm 0,35$ & $0,87 \pm 0,09$ & $4,7 \pm 0,08$ & $4,7 \pm 0,8$ & $4,7 \pm 0,8$ & $7,1 \pm 1,1$ \\
\hline
\end{tabular}

Результати мікробіологічних аналізів показали неоднорідність у чисельності еколого-трофічних груп мікроорганізмів верхнього шару грунту (0-20 см). Спостерігається зміна кількісної структури мікробного ценозу грунту в залежності від місця локалізації забруднення відходами та побічною продукцією виробництва. Так, наприклад, максимальна загальна чисельність грунтових мікроорганізмів відмічено в контрольному, незабрудненому варіанті.

Мінімальна кількість органотрофів у варіанті 3, що свідчить про значне пригнічення мікроорганізмів під впливом токсичних речовин фільтрату відходів. В той же час змінюється склад спорової бактеріальної мікробіоти: найбільше ії у варіанті 1, забрудненому метаболітами відходів забійного цеху та варіанті 3, забрудненому фільтратами 3 пташнику. Це є свідченням резистентності цієї № 4 (68), 2017 
Дем'янюк О. С., Тертична О. В., Симочко Л. Ю., Свалявчук Л. І.

еколого-трофічної групи до впливу полютантів. Мікроміцетів найбільше у варіанті 2, що пояснюється потраплянням у грунт решток підстилки 3 тирси, призводить до активізації целюлозоруйнівної мікрофлори.

Також у забруднених варіантах порівняно 3 контрольним зростає чисельність оліготрофів, здатних розвиватися на збіднених грунтах. I навпаки, кількість педотрофів зменшується, що $є$ свідченням зменшення поживних речовин у грунті.

Дослідженнями було передбачено оцінити токсичність грунту в зоні промислового бройлерного виробництва з використанням рослинних тест-систем. Зразки грунту для визначення токсичності відбирали за тими ж варіантами. В якості чутливих біот ест-об'єктів було обрано редис Raphanus sativus var. radicula Pers та гірчицю білу Sinapis alba L. Результати оцінки фітотоксичного ефекту (ФЕ) представлено у таблиці 2.

2. Фітотоксичний ефект (ФЕ) зразків грунту, відібраних в зоні промислового бройлерного птахопідприсмства, \%

\begin{tabular}{|l|c|c|}
\hline $\begin{array}{c}\text { Bapiaнт 3разка } \\
\text { Iрунту }\end{array}$ & $\begin{array}{c}\text { ФE Raphanus sativus var. } \\
\text { radicula Pers }\end{array}$ & $\begin{array}{c}\text { ФE } \\
\text { Sinapis alba }\end{array}$ \\
\hline Bаріант 1 & 62,3 & 55,2 \\
\hline Bаріант 2 & 48,0 & 43,5 \\
\hline Bаріант 3 & 87,4 & 77,1 \\
\hline Bаріант 4 & 31,8 & 25,5 \\
\hline Bаріант 5 & 20,3 & 18,2 \\
\hline
\end{tabular}

Результати, наведені в таблиці 2 свідчать про більш високу чутливість біотест-об’єкту редису досліджуваного грунту. Гірчиця біла є більш стійкою до дії фітотоксичних метаболітів, ФЕ у випадку іï використання значно менше. Найбільш токсичним виявився грунт, відібраний у 40 м від пташника, забруднений фільтратом відходів. В інших варіантах ФЕ значно більше ніж у контролі. Відповідно до шкали рівнів токсичності грунтів [6] грунт контрольного варіанту має слабкий рівень токсичності, на відстані 100 м можна віднести до середнього рівня. Грунт у варіанті 1 з високим рівнем токсичності, варіант 2 вище 
Дем'янюк О. С., Тертична О. В., Симочко Л. Ю., Свалявчук Л. І.

середнього рівня. Грунт у 3 варіанті (40 м від пташника із фільтратом відходів) є максимально токсичним.

Висновки. Отже, мікробіологічний аналіз грунтового мікробіоценозу, забрудненого відходами бройлерного виробництва свідчить про його значну трансформацію під впливом токсикантів. Найбільш стійкими виявилися угруповання оліготрофів та спороутворювальних бактерій, серед яких є багато видів здатних утворювати фітотоксичні екзометаболіти, що підтверджується фітотоксичним ефектом грунту на досліджуваних варіантах. Найменш резистентними можна вважати угруповання стрептоміцетів, i органотрофів. Вивчення токсичності грунту засвідчило, що більш чутливим біотест-об'єктом є Raphanus sativus var. radicula Pers порівняно 3 Sinapis alba L.

Отримані результати мікробіологічного аналізу свідчать про необхідність та перспективність проведення мікробіологічного моніторингу грунту. Екологічне оцінювання стану грунту в зонах ведення інтенсивного птахівництва нині $є$ актуальним з метою прогнозування подальших змін в мікробіоценозі під впливом антропогенної діяльності.

\section{Список літератури}

1. Екологічна оцінка стану довкілля в зонах виробництва продукції птахівництва / В.П. Бородай, О.В.Тертична, М.П.Кейван [та ін.] // Сучасне птахівництво. - 2014 - № 4 (137). - С. 22-25.

2. Берестецкий О. Методы определения токсичности почв / О. Берестецкий - Киев: Урожай, 1971. - С. 139 - 243.

3. Биорегуляция микробно-растительных систем: монография Г. А. Иутинская, С.П. Пономаренко, Е.И. Андреюк [и др.] ; под. ред. Г. А. Иутинской, С. П. Пономаренка. - К.: Ничлава, 2010. - 464 с.

4. Використання рослинних тест-систем для оцінки токсичності техногенно забруднених субстратів / 3. М. Бешлей , С. В. Бешлей , В. І. Баранов [та ін.] // Вісник Харківського національного аграрного університету серія біологія. - 2014. - Вип. 1 (31). - С. 97 - 102.

5. Горова А. Оцінка токсичності грунтів Червоноградського гірничопромислового району за допомогою ростового тесту / А. Горова, С. Кулина // Вісн. Львів. ун-ту. Серія біологічна. - 2008. - Вип. 48. - С . 189-194. 
Дем'янюк О. С., Тертична О. В., Симочко Л. Ю., Свалявчук Л. І.

6. Джура Н. М. Можливості використання рослинних тест-систем для біомоніторингу нафтозабруднених грунтів / Н. М. Джура // Біологічні студії / Studia Biologica. - 2011. - T. 5, № 3. - C. 183-196.

7. Експериментальна грунтова мікробіологія: монографія / В.В.Волкогон, О. В. Надкернична, Л. М. Токмакова [та ін.]; за наук. ред. В. В. Волкогона. - К.: Аграрна наука, 2010. - 464 с.

8. Медведев В. В. Мониторинг почв Украины / В. В. Медведев. - Харьков, 2002. $-428 \mathrm{c}$.

9. Патика В. П. Мікробіологічний моніторинг грунту природних та трансформованих екосистем Закарпаття України / В. П. Патика, Л. Ю. Симочко // Мікробіологічний журнал. - 2013. - Т.75, № 2. - С. 21-31.

10. Хазиев Ф. Х. Почва и биоразнообразие / Ф. Х. Хазиев // Экологя. -2011. - № 3. - C. 184-190.

11. Шерстобоєва О. В. Біологічний моніторинг грунтів як складова екологічного моніторингу агроекосистем / О. В. Шерстобоєва, Т. 3. Шустерук, О. С. Дем'янюк // Агроекологічний журнал. - 2007. - № 3. - С. 45-49.

12. Bardgett R. D. Biological diversity and function in soils / R. D. Bardgett, M. B. Usher. - Cambridge Univ.-Press, 2005. - 505 p.

13. Soil Ecology and Ecosystem Services / Editor-in-Chief D.H. Wall. - Oxford University Press, 2012. -405 p.

\section{References}

1. Borodai, V. P., Tertychna, O. V., Keivan, M. P., Bryhas, O. P., Masberh, I. V., Mineralov, O. I. (2014) Ekolohichna otsinka stanu dovkillia v zonakh vyrobnytstva produktsii ptakhivnytstva [Environmental assessment of the environment in the areas of poultry production]. Modern poultry farming, 4 (137), 22-25.

2. Berestetskiy, O. (1971) Metodyi opredeleniya toksichnosti pochv [Methods for determining the toxicity of soils]. Kiev: Urozhay, 139-243.

3. Iutinskoy, G.A., Ponomarenka, S.P. ed. (2010) Bioregulyatsiya mikrobnorastitelnyih system [Bioregulation of microbial and plant systems]. Kyiv: Nichlava, 464.

4. Beshlei, Z. M., Beshlei, S. V., Baranov V. I., Terek, O. I. (2014) Vykorystannia roslynnykh test-system dlia otsinky toksychnosti tekhnohenno zabrudnenykh substrativ [Using plant test systems for the evaluation of toxicity technologically contaminated substrates]. Bulletin of Kharkiv National Agrarian University: series biology, 1 (31), $97-102$.

5. Horova, A., Kulyna, S. (2008) Otsinka toksychnosti gruntiv Chervonohradskoho hirnychopromyslovoho raionu za dopomohoiu rostovoho testu [Evaluation of soil toxicity Chervonograd mining region using the growth test]. Visnyk of the Lviv university: series biology, 48, 189-194.

6. Dzhura, N.M. (2011) Mozhlyvosti vykorystannia roslynnykh test-system dlia biomonitorynhu naftozabrudnenykh gruntiv [Possibilities of using plant test systems for biomonitoring of oil contaminated soils]. Studia Biologica, 3, 183-196. 
Дем'янюк О. С., Тертична О. В., Симочко Л. Ю., Свалявчук Л. І.

7. Volkohona, V.V. ed. (2010) Eksperymentalna gruntova mikrobiolohiia [Experimental soil microbiology]. Kyiv: Ahrarna nauka, 464.

8. Medvedev, V.V. (2002) Monitoring pochv Ukrainyi [Monitoring of soils in Ukraine]. Harkov, 428.

9. Patyka, V.P., Symochko, L.Iu. (2013) Mikrobiolohichnyi monitorynh gruntu pryrodnykh ta transformovanykh ekosystem Zakarpattia Ukrainy [Microbiological monitoring of the soil of natural and transformed ecosystems of Transcarpathia of Ukraine]. Microbiological journal, №2, $21-31$.

10. Haziev, F.H. (2011) Pochva i bioraznoobrazie [Soil and biodiversity]. Ekology, № 3, 184-190.

11. Sherstoboieva, O.V., Shusteruk, T.Z., Demianiuk, O.S. (2007) Biolohichnyi monitorynh gruntiv yak skladova ekolohichnoho monitorynhu ahroekosystem [Biological monitoring of soils as a component of ecological monitoring of agroecosystems]. Agroecological journal, № 3, 45-49.

12. Bardgett, R.D., Usher, M.B. (2005) Biological diversity and function in soils. Cambridge Univ.-Press, 505.

13. Wall, D.H. ed. (2012) Soil Ecology and Ecosystem Services. Oxford: University Press, 405.

\section{ОСОБЕННОСТИ ФОРМИРОВАНИЯ МИКРОБИОЦЕНОЗА ПОЧВЫ В ЗОНЕ ПРОМЫШЛЕННОГО БРОЙЛЕРНОГО ПРОИЗВОДСТВА}

\section{О. С. Дем'янюк, О. В. Тертична, Л. Ю. Симочко, Л. І. Свалявчук}

Аннотация. Вопрос экологического оценивания микробиологического состояния почвы в зонах ведения промышленного птищеводства актуальны и важны для прогнозирования дальнейших изменений в биосфере под влиянием техногенеза. Целью исследования было обнаружить особенности формирования микробиоченоза почвы в зоне бройлерного производства по микробиологическим показателям и фитотоксическим эффектом. Микробиологические исследования почвы проводили общепринятыми методами почвенной микробиологии, рассчитывали токсичность почвы и фитотоксический эффект. Результаты микробиологических анализов показали, что наблюдается изменение количественной структуры микробного ценоза почвы, в зависимости от места локализачии загрязнения отходами и побочной продукиией производства. Максимальная общая численность почвенных микроорганизмов отмечена в контрольном, незагрязненном варианте. Минимальное количество органотрофов является свидетельством значительного подавления микроорганизмов под воздействием токсических веществ фильтрата отходов. В то же время меняется состав споровой бактериальной микробиоты, больше всего которой в почве загрязненной метаболитами отходов убойного цеха и загрязненными фильтратами из птичника. Увеличение микромицетов объясняется попаданием в почву остатков подстилки из опилок, приводит к активизаџии целлюлозно- 
Дем'янюк О. С., Тертична О. В., Симочко Л. Ю., Свалявчук Л. І.

разрушительной микрофлоры. Также в загрязненных вариантах по сравнению с контрольным растет численность олиготрофов, способных развиваться на бедных почвах. Количество педотрофов уменьшается, что свидетельствует об уменьшении питательных веществ в почве. Оченены токсичность почвы в зоне промышленного бройлерного производства с использованием растительных биотестов Raphanus sativus var. radicula Pers u Sinapis alba L. Показана более высокая чувствительность биотест - объекта редиса. Горчица белая более устойчивая к действию фитотоксических метаболитов. Наиболее токсичной оказалась почва, отобранная в $40 \mathrm{M}$ от птичника, загрязненная фильтратом отходов.

Таким образом, микробиологический анализ почвы, загрязненной отходами бройлерного производства свидетельствует о значительной трансформации микробных сообществ под влиянием токсикантов. Перспективным направлением дальнейших исследований является проведение микробиологического мониторинга почв в зонах ведения интенсивного бройлерного производства.

Ключевые слова: птицеводство, бройлерное производство, почва, загрязнения, микроорганизмы, фитотоксичность

\section{FORMATION FEATURES OF SOIL MICROBIOCENOSIS IN THE ZONE OF INDUSTRIAL BROILER PRODUCTION O.S. Demianiuk, O. V. Tertychna, L.Iu. Symochko, L.I. Svaliavchuk}

Abstract. Issues of environmental assessment of the soil microbiological state in the zones of industrial poultry management are relevant and important for predicting further changes in the biosphere under the influence of technogenesis.

The aim of the study was to identify the features of formation of soil microbiocenosis in the zone of broiler production by microbiological indices and phytotoxic effect. Microbiological studies of soil were carried out by standards methods of soil microbiology, soil toxicity and phytotoxic effects were calculated.

The results of microbiological analyzes showed that there is a change in the quantitative structure of the soil microbial cenosis, depending on the location of the contamination.

The maximum total number of soil microorganisms was in control, noncontaminated area. The minimum number of organotrophs is evidence of significant inhibition of microorganisms under the influence of toxic substances of waste filtrate. At the same time was changing the composition of the spore microbiota, most of it observed in the soil polluted of metabolites of the slaughterhouse waste and contaminated with filtrate from the poultry. Increase of micromycetes due to the entry into the soil of the remains of litter from sawdust, leads to activation of cellulosedestroying microbiota. Also, in contaminated variants, as compared to control, the number of oligotrophs that can develop on depleted soils increases. The number of pedotrophs decreases, which is evidence of a decrease in nutrients in the soil. The 
Дем'янюк О. С., Тертична О. В., Симочко Л. Ю., Свалявчук Л. І.

toxicity of soil in the zone of industrial broiler production was estimated by using biotests Raphanus sativus var. Radicula Pers and Sinapis alba L. Showing higher sensitivity of radish, as biotest - object. Mustard white is more resistant to phytotoxic metabolites. The most toxic soil was found $40 \mathrm{~m}$ from a poultry house, polluted with waste filtrate. Consequently, the microbiological analysis of the soil contaminated with waste from broiler production indicates a significant transformation of microbial community under the influence of toxicants. Prospects for further research are to find ways of soil remediation contaminated with waste of poultry production, which is an important area of ecologization of poultry farming.

Keywords: poultry farming, broiler production, soil, contamination, microorganisms, phytotoxicity 